(1)

\title{
ANALISIS FAKTOR-FAKTOR YANG MEMPENGARUHI TINGKAT FINANCIAL DISTRESS PADA PERUSAHAAN MANUFAKTUR YANG TERDAFTAR DI BEI TAHUN 2010-2014
}

\author{
Mayang Murni \\ Program Studi Akuntansi Politeknik LP3I Medan \\ *Corresponding author: E-mail: mayang.ashari@gmail.com

\section{Abstrak}

Tujuan penelitian ini adalah untuk menguji pengaruh ukuran, umur perusahaan, CR, DER, ROA, ROE, NPM, EPS dan PER terhadap tingkat financial distresss. Populasi dalam penelitian ini adalah perusahaan kelompok manufaktur yang terdaftar di Bursa Efek Indonesia (BEI) pada periode 2010-2014. Penarikan sampel dalam penelitian ini menggunakan metode purposive sampling, yaitu teknik penentuan sampel berdasarkan kriteria tertentu. Sehingga sampel yang digunakan adalah 73 perusahaan kelompok manufaktur yang terdaftar di Bursa Efek Indonesia (BEI). Jadi jumlah pengamatan dalam penelitian ini sebanyak 365 pengamatan. Jenis data yang digunakan dalam penelitian ini adalah data skunder yang berasal dari laporan keuangan. Data tersebut dianalisis dengan menggunakan teknik regresi linier berganda yang dibantu dengan program SPSS 21. Ukuran perusahaan, Current Ratio,DER, ROE, EPS dan PER memiliki pengaruh yang negative tidak signifikan terhadap tingkat financial distress. Sementara, umur perusahaan pengaruh yang positif tetapi tidak signifikan terhadap tingkat financial distress dan NPM memiliki pengaruh yang positif signifikan terhadap tingkat financial distress.

Kata kunci : Ukuran Perusahaan, Umur Perusahaan, CR, DER, ROA, ROE, NPM, EPS dan PER, Tingkat financial distresss.

\begin{abstract}
The objective of the research was to examine the influence of size, firm age, CR, DER, ROA, ROE, NPM, EPS, and PER on financial distress level with. The population was manufacture companies listed in BEI (the Indonesia Stock Exchange) in the period of 2010-2014. The samples were 73 manufacture companies listed in BEI, taken by using purposive sampling technique so that there were 365 observations. The data were secondary data which were obtained from financial statement. The gathered data were analyzed by using multiple linear regression analysis and path analysis with an SPSS 21 software program. The result of the research showed that ROA had negative and significant influence on financial distress level. Firm size, Current Ratio, DER, ROE, EPS, and PER had negative and insignificant influence on financial distress level. Meanwhile, firm age had positive but insignificant influence on financial distress level, and NPM had positive and significant influence on financial distress level.
\end{abstract}

Keywords: Firm Size, Firm Age, CR, DER, ROA, ROE, NPM, EPS, and PER, Level Of Financial Distress 


\section{PENDAHULUAN}

Naik turunnya harga saham dipasar modal menjadi sebuah fenomena yang menarik untuk dibicarakan. Krisis ekonomi global yang terjadi pada tahun 2008 berdampak besar terhadap pasar modal Indonesia yang tercermin dari terkoreksi turunnya harga saham hingga 40-60 persen dari posisi awal tahun 2008 (kompas.com), yang disebabkan oleh aksi melepas saham oleh investor asing yang membutuhkan likuiditas dan diperparah dengan aksi "iku-ikutan" dari investor domestic yang ramai-ramai melepas sahamnya.

Financial distress menurut Afriyeni (2012)adalah kondisi dimana keuangan perusahaan dalam keadaan tidak sehat atau krisis.Financial distress yang cukup mengganggu kegiatan operasional perusahaan merupakan suatu kondisi yang harus segera diwaspadai dan diantisipasi.

Menurut Rodoni dan Ali dalam Afriyeni (2012), apabila ditinjau dari kondisi keuangan ada tiga keadaan yang menyebabkan financial distress yaitu faktor ketidakcukupan modal atau kekurangan modal, besarnya beban utang dan bunga serta menderita kerugian. Ketiga aspek tersebut saling berkaitan.Oleh karena itu harus dijaga keseimbangannya agar perusahaan terhindar dari kondisi financial distress yang mengarah kepada kebangkrutan.

Kondisi financial distress merupakan kondisi yang tidak diinginkan oleh berbagai pihak. Jika terjadi financial distress, maka investor dan kreditor akan cenderung berhatihati dalam melakukan investasi atau memberikan pinjaman pada perusahaan terse but. Stakeholder akan cenderung bereaksi negatif terhadap kondisi ini. Oleh karena itu, manajemen perusahaan harus segera mengambil tindakan untuk mengatasi masalah financial distress dan mencegah kebangkrutan.

Terdapat beberapa indicator atau sumber informasi tentang kemungkinan financial distress.
Sejumlah studi telah dilakukan untuk mengetahui kegunaan analisis rasio keuangan dalam menilai tingkat kesulitan keuangan (financial distress) usaha.Dalam menganalisis rasio keuangan dapat dilihat dari laporan keuangan.Laporan Keuangan yang baik seharusnya memberikan informasi yang berguna bagi pihak yang berkepentingan (investor dan kreditor) untuk membuat suatu kebijakan dan keputusan investasi, kredit dan sejenisnya.jika perusahaan dengan kinerja baik, perusahaan tersebut memberikan sinyal baik kepada investor terkait kondisi perusahaan sehingga dengan melihat kinerja perusahaan yang baik maka akan mengakibatkan nilai perusahaan meningkat dan banyak investor yang berkeinginan menanamkan modal diperusahaan.

Investor menilai suatu perusahaan dalam menanamkan modalnya disuatu perusahaan melihat kondisi keuangannya yang diproxykan dengan CR, DER, ROA, ROE, NPM, EPS, PER serta factor umur perusahaan dan ukuran perusahaan itu sendiri. Jika perusahaan tersebut mencapai prestasi yang baik maka akan lebih diminati investor. Hal ini sesuai dengan signaling theory.

Sementara financial distress adalah factor yang sangat dihindari oleh perusahaan dan investor.Tanuwijaya (2013) menyebutkan bahwa factor-faktor keuangan yang diwakili dengan rasio likuiditas, rasio pasar, kepemilikan manajerial dan kepemilikan institusional mempunyai pengaruh signifikan positif terhadap tingkat financial distress.

\section{Tingkat Financial Distress}

Financial distress menurut Afriyeni (2012)adalah kondisi dimana keuangan perusahaan dalam keadaan tidak sehat atau krisis.Tingkat financial distress yang dialami suatu perusahaan dengan menggunakan metode Alman Z-Score.

$$
\begin{gathered}
\mathrm{Z}-\mathrm{Score}=1.2 \mathrm{~T}_{1}+{ }^{1.4 \mathrm{~T}_{2}}+3.3 \mathrm{~T}_{3}+\mathrm{0.6T}_{4}+ \\
\mathbf{0 . 9 9 9}_{5}
\end{gathered}
$$

Dimana; 
$\mathrm{T}_{1}$ : Working capital/ total assets

$\mathrm{T}_{2}$ : Retained earnings/ total assets

$\mathrm{T}_{3}$ :Earnings Before Interest and Taxes /

Total Assets

$\mathrm{T}_{4}$ :Market Value of Equity / Total Liabilities

$\mathrm{T}_{5}$ : Sales/ Total Assets

1. Ukuran Perusahaan

Menurut Grier (1994) dalam Christiawan (2014), ukuran perusahaan mempunyai pengaruh yang berbeda terhadap harga saham. Dalam hal ini ukuran perusahaan dilihat dari log total assets yang dimiliki oleh perusahaan, yang dapat dipergunakan untuk kegiatan operasi perusahaan.

Ukuran Perusahaan $=$ Ln TotalAktiva

\section{Umur Perusahaan}

Menurut Bestivano (2013), umur perusahaan adalah umur sejak berdirirnya perusahaan hingga perusahaan telah mampu menjalankan operasinya.

\section{Current Ratio (CR)}

Harahap (2011) mengemukakan bahwa current ratio merupakan rasio yang digunakan untuk mengukur kemampuan perusahaan dalam membayar kewajiban jangka pendeknya.Current Ratio diukur dengan membandingkan antara asset lancer dan kewajiban lancar.

$$
\text { CurrentRatio }=\frac{\text { CurrentAssets }}{\text { CurrentLiability }}
$$

\section{Debt to Equity Ratio (DER)}

Harahap (2011), Debt to Equity adalah rasio hutang terhadap ekuitas yaitu mencerminkan kemampuan perusahaan dalam memenuhi seluruh kewajibannya yang ditunjukkan oleh berapa bagian dari modal sendiri yang digunakan untuk membayar hutang.

$$
\text { DebttoEquityRatio }=\frac{\text { TotalLiability }}{\text { OwnersEquity }}
$$

\section{Return on Assets (ROA)}

Hermanto (2012) menyatakan bahwa Return on Assets (ROA) adalah rasio yang digunakan dalam menggambarkan ukuran efektivitas perusahaan dalam memanfaatkan seluruh sumber dayanya. Return on Assets (ROA) menghitung dengan membandingkan laba bersih setelah pajak dengan total asset.

$$
R O A=\frac{E A T}{\text { TotalAssets }}
$$

\section{Return on Equity (ROE)}

Brigham dan Houston (2009), Return on Equity (ROE) merupakan tingkat pengembalian ekuitas biasa adalah mengukur tingkat pengembalian atas investasi dari pemegang saham biasa. Return on Equity (ROE) didapat dengan membandingkan laba bersih setelah pajak dengan ekuitas perusahaan.

$$
R O E=\frac{E A T}{\text { Equity }}
$$

\section{Net Profit Margin (NPM)}

Harahap (2011) mengemukakan Net Profit Margin (NPM) yaitu rasio yang menggambarkan besarnya laba bersih yang diperoleh perusahaan pada setiap penjulan yang dilakukan.

$$
\text { NetProfitMargin }=\frac{E A T}{\text { Sales }}
$$

\section{Earning Per Share (EPS)}

Fahmi (2012), Earning Per Share (EPS) adalah bentuk pemberian keuntungan yang diberikan kepada para pemegang saham dari setiap lembar saham yang dimiliki. 


$$
E P S=\frac{\text { Profitshare }}{\text { TotalShare }}
$$

\section{Price Earning Ratio (PER)}

Menurut Jogiyanto (2003), Price Earing Ratio (PER) merupakan ukuran untuk menentukan bagaimana pasar memberikan nilai atau harga pada saham perusahaan. Price Earing Ratio (PER) didapat dengan membandingkan harga pasar saham dengan laba bersih yang diperoleh.

$$
\text { PER }=\frac{\text { MarketSharePrice }}{\text { NetProfit }}
$$

\section{B. METODE PENELITIAN}

Jenis penelitian ini adalah kausal komparatif.Penelitian ini dilakukan pada perusahaan manufaktur yang terdaftar di Bursa Efek Indonesia dengan periode amatan 2010-2014.Populasi penelitian sebanyak 101 perusahaan. Kriteria pemilihan sampel dengan cara purposive sampling, dengan criteria sebagai berikut ;

1. Merupakan perusahan sector manufaktur yang terdaftar di Bursa Efek Indonesia sepanjang tahun amatan

Dengan kerangka konseptual penelitian :
2. Mempublikasikan laporan keuangan yang dilengkapi dengan variabel-variabel yang diamati selama tahun amatan

Berdasarkan criteria tersebut diperoleh sampel sebanyak 73 perusahaan selama 5 tahun dengan total 365 data observasi. Metode analisis data dalam penelitian ini menggunakan statistic deskriptif. Berikut merupakan persamaan regresi dalam penelitian ini :

$$
\begin{gathered}
Y=\alpha+\beta_{1} X_{1}+\beta_{2} X_{2}+\beta_{3} X_{3}+\beta_{4} X_{4}+\beta_{5} X_{5}+ \\
\beta_{6} X_{6}+\beta_{7} X_{7}+\beta_{8} X_{8}+\beta_{9} X_{9}+\varepsilon
\end{gathered}
$$

\section{Keterangan :}

$$
\begin{array}{ll}
\mathrm{Y} & =\text { Tingkat Financial Distress } \\
\alpha & =\text { Konstanta } \\
\mathrm{X}_{1} & =\text { Ukuran Perusahaan } \\
\mathrm{X}_{2} & =\text { Umur Perusahaan } \\
\mathrm{X}_{3} & =\mathrm{CR} \\
\mathrm{X}_{4} & =\text { DER } \\
\mathrm{X}_{5} & =\text { ROA } \\
\mathrm{X}_{6} & =\text { ROE } \\
\mathrm{X}_{7} & =\text { NPM } \\
\mathrm{X}_{8} & =\mathrm{EPS} \\
\mathrm{X}_{9} & =\text { PER } \\
\beta_{1-} \beta 9, \rho & =\text { Koefisien } \\
\varepsilon & =\text { error }
\end{array}
$$

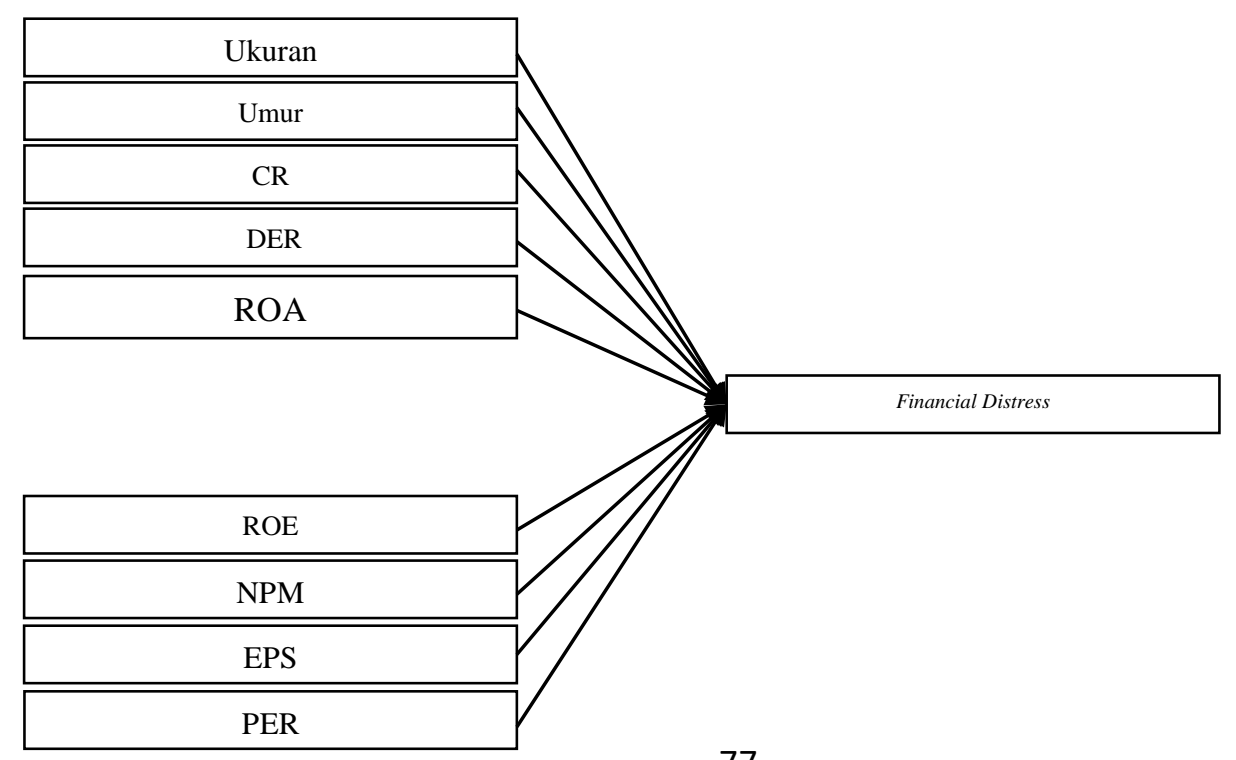




\section{Gambar 1. Kerangka Konseptual}

HASIL DAN PEMBAHASAN

\section{Statistik Deskriptif}

Tabel 1. Descriptive Statistics

\begin{tabular}{|c|r|r|r|r|r|}
\hline & N & Minimum & Maximum & Mean & \multicolumn{1}{c|}{ Std. Deviation } \\
\hline UkuranPerusahaan & 365 & 23.27 & 38.26 & 27.9815 & 2.03919 \\
UmurPerusahaan & 365 & 2 & 37 & 19.15 & 5.975 \\
CurrentRatio & 365 & 8 & 46488 & 411.65 & 2743.743 \\
DER & 365 & -3060.26 & 12742.95 & 137.4551 & 727.93007 \\
ROA & 365 & -42.04 & 280.96 & 7.6671 & 18.34090 \\
ROE & 365 & -608.81 & 968.55 & 13.7425 & 70.28091 \\
NPM & 365 & -204.04 & 409.75 & 6.3145 & 26.74865 \\
EPS & 365 & -3134.00 & 55576.00 & 830.1680 & 4400.50032 \\
PER & 365 & -1400.00 & 3350.00 & 22.3610 & 211.59169 \\
& & & & 1.7096 & .83076 \\
FinancialDistress & 365 & & & & \\
Valid N (listwise) & 365 & & & & \\
\hline
\end{tabular}

Sumber : Hasil Penelitian, 2016 (Data diolah)

\section{Pengujian Asumsi Klasik}

Uji Normalitas

Uji normalitas residual dilakukan dengan uji statistic non parametric KolmogorovSmirnov (K-S). Nilai Kolmogorov-Smirnov Z sebesar 0,701 dan signifikansinya pada 0,710 nilainya diatas $\alpha=0,05$ (Asymp. Sig $=0,710$ $>0,05)$. Maka dapat disimpulkan bahwa data penelitian berdistribusi secara normal.

Uji Multikolinieritas

Uji multikolinieritas dilakukan dengan menggunakan variance inflation factor (VIF). Data dikatakan tidak mengalami multikolinieritas apabila nilai VIF $\leq 10$.Hasil pengujian menunjukkan seluruh variabel independen memiliki nilai $\mathrm{VIF} \leq 10$ sehingga data penelitian ini tidak mengalami multikolinieritas.

Uji Heterokedastisitas

Tabel 5. Model Summary

\begin{tabular}{|c|r|r|r|r|}
\hline Model & R & R Square & Adjusted R Square & $\begin{array}{c}\text { Std. Error of the } \\
\text { Estimate }\end{array}$ \\
\hline 1 & $.329^{\mathrm{a}}$ & .108 & .077 & .86986 \\
\hline
\end{tabular}

a. Predictors: (Constant), X9, X5, X4, X6, X2, X3, X1, X8, X7
Uji heterokedastisitas dilakukan dengan melihat pada grafik scatterplot yaitu sebaran plot tidak membentuk pola tertentu dan tersebar diatas dan dibawah angka 0 pada sumbu Y. Berdasarkan hasil pengujian diketahui sebaran plot pada grafik scatterplot tidak membentuk pola tertentu dan menyebar diatas dan dibawah angka 0 pada sumbu $Y$, maka dikatakan bahwa seluruh variabel dalam penelitian terbebas dari asumsi heterokedastisitas.

Pengaruh Ukuran Perusahaan, Umur Perusahaan, CR, DER, ROA, ROE, NPM, EPS Dan PER Terhadap Tingkat Financial Distress Secara Parsial dan Simultan 
Berdasarkan tabel diatas diketahui nilai $R$ umur perusahaan, CR, DER, ROA, ROE, Square sebesar 0,108 yang artinya adalah NPM, EPS dan PER. Sisanya 89,2\% sebesar $10,8 \%$ variabel tingkat financial dijelaskan oleh faktor lainnya diluar model distress dijelaskan oleh ukuran perusahaan, penelitian.

Tabel 6. ANOVA ${ }^{\mathrm{a}}$

\begin{tabular}{|c|c|c|c|c|c|c|}
\hline \multicolumn{2}{|r|}{ Model } & Sum of Squares & Df & Mean Square & $\mathrm{F}$ & Sig. \\
\hline \multirow{3}{*}{1} & Regression & 23.176 & 9 & 2.575 & 3.403 & $.001^{\mathrm{b}}$ \\
\hline & Residual & 190.680 & 252 & .757 & & \\
\hline & Total & 213.855 & 261 & & & \\
\hline
\end{tabular}

a. Dependent Variable: y

b. Predictors: (Constant), X9, X5, X4, X6, X2, X3, X1, X8, X7

Diketahui nilai uji F sebesar 3,403 dengan sig NPM, EPS dan PER memiliki pengaruh yang 0,001 . Artinya variabel ukuran perusahaan, signifikan terhadap tingkat financial distress umur perusahaan, CR, DER, ROA, ROE, $(0,001<0,05)$.

Tabel 7. Coefficients ${ }^{\mathrm{a}}$

\begin{tabular}{|c|r|r|r|r|r|}
\hline \multirow{2}{*}{ Model } & \multicolumn{2}{|c|}{$\begin{array}{c}\text { Unstandardized } \\
\text { Coefficients }\end{array}$} & \multicolumn{2}{c|}{$\begin{array}{c}\text { Standardized } \\
\text { Coefficients }\end{array}$} & \multicolumn{1}{c|}{ Sig. } \\
\cline { 2 - 4 } & \multicolumn{1}{|c|}{ B } & \multicolumn{1}{c|}{ Std. Error } & Beta & & \\
\hline \multirow{4}{*}{ (Constant) } & 1.947 & 4.348 & & .448 & .655 \\
X1 & -.884 & 3.020 & -.023 & -.293 & .770 \\
X2 & .148 & .208 & .043 & .712 & .477 \\
X3 & -.349 & .206 & -.106 & -1.696 & .091 \\
X4 & -.147 & .143 & -.065 & -1.026 & .306 \\
X5 & -.466 & .111 & -.256 & -4.176 & .000 \\
X6 & -.224 & .223 & -.114 & -1.008 & .315 \\
X7 & .425 & .215 & .221 & 1.974 & .049 \\
X8 & -.092 & .086 & -.103 & -1.060 & .290 \\
X9 & -.037 & .081 & -.035 & -.460 & .646 \\
\hline
\end{tabular}

a. Dependent Variable: y

Persamaan struktural yang dibangun untuk hipotesis ini yaitu :

$$
\begin{aligned}
\mathrm{y}= & -0,884 \mathrm{X}_{1}+0,148 \mathrm{X}_{2}-0,349 \mathrm{X}_{3}-0,147 \mathrm{X}_{4}- \\
& 0,466 \mathrm{X}_{5}-0,224 \mathrm{X}_{6}+0,425 \mathrm{X}_{7}-0,092 \mathrm{X}_{8}- \\
& 0,037 \mathrm{X}_{9}
\end{aligned}
$$

Pengaruh ukuran perusahaan $\left(\mathrm{X}_{1}\right)$ terhadap tingkat financial distress $(\mathrm{Z})$ sebesar $-0,884$ dengan sig $0,770>0,05$ artinya ukuran perusahaan $\left(\mathrm{X}_{1}\right)$ memiliki pengaruh yang negatif tetapi tidak signifikan terhadap tingkat financial distress (Z). Pengaruh umur perusahaan $\left(\mathrm{X}_{2}\right)$ terhadap tingkat financial distress (Z) sebesar 0,148 dengan sig 0,477 > 0,05 artinya umur perusahaan $\left(\mathrm{X}_{2}\right)$ memiliki pengaruh yang positif tetapi tidak signifikan terhadap tingkat financial distress ( $\mathrm{Z}$ ). Pengaruh current ratio $\left(\mathrm{X}_{3}\right)$ terhadap tingkat 
financial distress sebesar -0,349 dengan sig 0,091>0,05 artinya CR $\left(\mathrm{X}_{3}\right)$ memiliki pengaruh yang negatif tetapi tidak signifikan terhadap tingkat financial distress (Z). Pengaruh Debt to Eqity Ratio $\left(\mathrm{X}_{4}\right)$ terhadap tingkat financial distress (Z) sebesar $-0,147$ dengan sig 0,306 > 0,05 artinya DER $\left(\mathrm{X}_{4}\right)$ memiliki pengaruh negatif tetapi tidak signifikan terhadap tingkat financial distress (Z). Pengaruh Return On Assets ( $\left.\mathrm{X}_{5}\right)$ terhadap tingkat financial distress (Z) sebesar-0,466 dengan sig $0,000<0,005$ artinya ROA $\left(\mathrm{X}_{5}\right)$ memiliki pengaruh yang negatif dan signifikan terhadap tingkat financial distress (Z). Pengaruh Return On Equity $\left(\mathrm{X}_{6}\right)$ terhadap tingkat financial distress ( $\mathrm{Z}$ ) sebesar -0,224 dengan sig 0,315 $>0,05$ artinya $\operatorname{ROE}\left(\mathrm{X}_{6}\right)$ memiliki pengaruh yang negatif tidak signifikan terhadap tingkat financial distress (Z). Pengaruh Net Profit Margin $\left(\mathrm{X}_{7}\right)$ terhadap tingkat financial distress $(\mathrm{Z})$ sebesar 0,425 dengan sig 0,049 $<0,05$ artinya NPM $\left(X_{7}\right)$ berpengaruh positif dan signifikan terhadap tingkat financial distress $(\mathrm{Z})$. Pengaruh earning per share $\left(\mathrm{X}_{8}\right)$ terhadap tingkat financial distress $(\mathrm{Z})$ sebesar -0,092 dengan sig 0,290 artinya EPS $\left(X_{8}\right)$ berpengaruh negatif tidak signifikan terhadap tingkat financial distress (Z). Pengaruh Price Earning Ratio $\left(\mathrm{X}_{9}\right)$ terhadap tingkat financial distress $(\mathrm{Z})$ sebesar -0,037 dengan sig 0,646 $>0,05$ artinya PER $\left(\mathrm{X}_{9}\right)$ memiliki pengaruh yang negatif tidak signifikan terhadap tingkat financial distress $(\mathrm{Z})$.

Berdasarkan hasil uji hipotesis diatas diketahui bahwaukuran perusahaan memiliki pengaruh yang negatif tetapi tidak signifikan terhadap tingkat financial distress. Dengan demikian penelitian ini sejalan dengan teori bahwa ukuran perusahaan memiliki pengaruh yang negatif terhadap tingkat financial distress. Perusahaan yang memiliki ukuran yang besar yang dinilai dari Ln Total Aktiva, maka semakin rendah kemungkinan financial distress terjadi dalam perusahaan tersebut. Perusahaan dengan pertumbuhan yang positif memberikan suatu tanda bahwa ukuran perusahaan tersebut semakin berkembang dan mengurangi kecenderungan ke arah kebangkrutan.Penelitian ini sejalan dengan penelitian yang dilakukan oleh Hastuti (2014) yang mendapatkan hasil bahwa ukuran perusahaan berpengaruh negatif terhadap tingkat financial distress.

Umur perusahaan memiliki pengaruh positif tetapi tidak signifikan terhadap tingkat financial distress. Hasil ini tidak sejalan dengan teori bahwa ukuran perusahaan berpengaruh negatif dan signifikan terhadap tingkat financial distress. Hasil ini sejalan dengan penelitian yang dilakukan oleh Ramdhani (2009). Umur suatu perusahaan tidak selalu menjamin bahwa perusahaan tersebut merupakan perusahaan yang memiliki kondisi keuangan yang sehat.baik perusahaan tersebut berumur muda ataupun tua perusahaan tersebut memiliki kemungkinan untuk diprediksi bangkrut tergantung dari kondisi keuangan perusahaan tersebut.

Current ratio memiliki pengaruh yang negatif tetapi tidak signifikan terhadap tingkat financial distress. Dengan demikian penelitian ini sesuai dengan teori bahwa CR memiliki pengaruh negatif terhadap tingkat financial distress. Sesuai dengan teori Brigham dan Houston (2001), bahwa jika kewajiban lancar meningkat lebih cepat dibandingdkan aktiva lancar, maka rasio lancar akan turun dan hal ini bisa menimbulkan permasalahan, maka dapat dimungkinkan bahwa pola hubungan antara current ratio dengan probabilitas kebangkrutan adalah negative. Hal ini sejalan dengan penelitian Almilia (2003) menyatakan bahwa current ratio memiliki 
pengaruh negatif dan signifikan terhadap financial distress. Artinya semakin tinggi current ratio maka semakin rendah tingkat financial distress suatu perusahaan.

Debt to Equity Ratio (DER) memiliki pengaruh negatif terhadap tingkat financial distress. Hal ini tidak sejalan dengan teori bahwa DER memiliki pengaruh positif dan signifikan terhadap tingkat financial distress. Hasil ini sejalan dengan penelitian yang dilakukan oleh Tanuwijaya (2013), yang menyatakan bahwa DER memiliki pengaruh yang negatif terhadap tingkat financial distress. Hal ini kemungkinan disebabkan oleh biaya relatif yaitu biaya utang lebih kecil dari biaya ekuitas (Apricia, 2010). Perusahaan dengan keputusan penggunaan utang dalam neracanya secara umum dapat meningkatkan profitabilitasnya, yang kemudian menaikkan harga sahamnya, sehingga meningkatkan kesejahteraan para pemegang saham serta membangun potensi pertumbuhan yang lebih besar dan mengecilkan potensi financial distress.

Return on Assets (ROA) memiliki pengaruh negatif dan signifikan terhadap tingkat financial distress. Penelitian ini sejalan dengan teori bahwa ROA memiliki pengaruh yang negatif terhadap tingkat financial distress. Return on Asset merupakan rasio profitabilitias yang mendeteksi atau mengukur kemampuan perusahaan dalam menghasilkan keuntungan dalam periode tertentu dan yang mengatur akumulasi laba selama perusahaan beroperasi. Apabila rasio ROA rendah menunjukkan kemampuan aktiva perusahaan kurang produktif dalam menghasilkan laba, dan kondisi seperti ini akan mempersulit keuangan perusahaan dalam sumber pendanaan internal untuk investasi, sehingga dapat menyebabkan terjadinya probabilitas kebangkrutan. Jadi, dapat dismpulkan bahwa rasio ROA mempunyai pola hubungan negatif terhadap probabilitas kebangkrutan. Hal ini sejalan dengan penelitian yang dilakukan oleh Andre (2013).

Return on Equity (ROE) memiliki pengaruh yang negatif tetapi tidak signifikan terhadap tingkat financial distress. Penelitian ini sejalan dengan teori bahwa ROE memiliki hubungan negatif terhadap tingkat financial distress. ROE rendah menunjukkan perusahaan kurang memiliki kemampuanmenggunakan ekuitas untuk menghasilkan laba, dan semakin mempersulit keuangan perusahaan dalam sumber pendanaan internal untuk investasi, sehingga dapat menyebabkan terjadinya financial distress atau probabilitas kebangkrutan.Hal ini sejalan dengan penelitian yang dilakukan oleh Kamaludin (2011).

Net Profit Margin (NPM) memiliki pengaruh yang positif dan signifikan terhadap tingkat financial distress. Penelitian ini tidak sejalan dengan teori bahwa NPM berpengaruh negatif terhadap tingkat financial distress. Hasil ini bertentangan dengan penelitian yang dilakukan Haq (2013).Apricia (2010) mengemukakan bahwa NPM yang rendah tidak selalu merupakan indikator yang buruk bagi perusahaan dan kecenderungan financial distress. Perusahaan dapat menurunkan harga jual yang biasanya akan meningkatkan volume penjualannya, tetapi secara normal akan menurunkan profit margin tetapi tidak mempengaruhi kondisi keuangan perusahaan dalam arti probabilitas financial distress.

Earning Per Share (EPS) memiliki pengaruh yang negatif terhadap tingkat financial distress. Penelitian ini sejalan dengan teori bahwa EPS berpengaruh negatif terhadap tingkat financial distress. Hal ini sejalan dengan penelitian Apricia (2010). Tingkat EPS dimasa yang akan datang dapat 
digunakan untuk melihat tingkat pertumbuhan perusahaan secara keuangan. Artinya EPS yang tinggi memberikan probabilitas yang rendah terhadap tingkat financial distresssi atau hubungan kedua nya negatif.Price Earning Ratio (PER) memiliki pengaruh negatif terhadap tingkat financial distress. Penelitian ini sejalan dengan teori bahwa PER memiliki pengaruh yang negatif terhadap harga saham. Perusahaan dengan PER yang tinggi memiliki probabilitas kebangkrutan yang rendah, dengan kata lain bahwa PER memiliki pola hubungan yang negatif terhadap tingkat financial distress. Hal ini sejalan dengan penelitian yang dilakukan oleh Tanuwijaya (2013) yang mendapatkan hasil bahwa PER memiliki hubungan yang negatif terhadap financial distress. Selanjutnya secara simultan pengaruh ukuran, umur perusahaan, current ratio, debt to equity ratio, ROA, ROE, NPM, EPS dan PER signifikan terhadap tingkat financial distress.

\section{KESIMPULAN}

Dari hasil penelitian yang dilakukan dapat diambil kesimpulan sebagai berikut : ROA memiliki pengaruh yang negative dan signifikan terhadap tingkat financial distress. Ukuran perusahaan, Current Ratios DER, ROE, EPS dan PER memiliki pengaruh yang negative tidak signifikan terhadap tingkat financial distress.NPM memiliki pengaruh positif dan signifikan terhadap tingkat financial distress.Sementara umur perusahaan memiliki pengaruh yang positif tetapi tidak signifikan terhadap tingkat financial distress. Secara simultan ukuran, umur perusahaan, current ratio, debt to equity ratio, ROA, ROE, NPM, EPS dan PER berpengaruh signifikan terhadap tingkat financial distress.

\section{DAFTAR PUSTAKA}

A, E. 2012."Model Prediksi Financial Distress". Padang. Polibisnis, Volume 4 No. 2 Oktober 2012Altman, Edward I. (1968). Financial Ratios, Discriminant Analysis and The Prediction of Corporate Banckrupptcy. The Journal of Finance.September. Vol. XXIII, No 4, p. 589-609.

A, P. dan P.P. 2001.Pengantar Pasar Modal. Jakarta.Edisi Revisi. PT Asdi Mahasatya.

B, W. 2013. "Pengaruh Ukuran Perusahaan, Umur Perusahaan, Profitabilitas, dan Leverage Terhadap Perataan Laba Pada Perusahaan yang Terdaftar di BEI (Studi Empiris pada Perusahaan Perbankan di BEI)". Padang. Universitas Negeri Padang

B, E.F dan H, J.F, 2009.Manajemen Keuangan, Terjemahan, Edisi Kedelapan, Jakarta: Penerbit Erlangga.

F, I. 2012. "Pengantar Pasar Modal". Bandung. Alfabeta Edisi IGhozali, Imam. 2011. "Analisis Multivariate dengan Program SPSS”. Semarang. Badan Penerbit Universitas Diponegoro.

H, S.S. 2009. “Analisis Kritis Atas Laporan Keuangan". Jakarta: Raja Grafindo Persada.

L, et al. 2012."The Prediction Of Financial Distress Analysis And Its Implication To Stock Price's Sub Sector Transportation In Indonesia Stock Exchange Period 2007-2011”. 11th Ubaya International Annual Symposium On Management 
N, I. 2013. "Peranan Analisis Metode ZScore Dalam Memprediksi Kebangkrutan Suatu Perusahaan Dan Kaitannya Terhadap Harga Saham (Studi Pada Perusahaan Perbankan Yang Go Public Di Bursa Efek Indonesia )’. Siliwangi. Universitas Siliwangi

T, L. 2013. “Analisis Faktor-Faktor Internal dan Eksternal Perusahaan yang Mempengaruhi Kesulitan Keuangan (Financial Distress) Pada Perusahaan Sektor Manufaktur Yang Terdaftar di BEI'.Semarang. Universitas Katolik Soegijapranata

$\underline{\text { www.idx.co.id }}$ 